\title{
Diversity and potential application of endophytic bacteria in ginger
}

T. Chen ${ }^{1}$, Z. Chen ${ }^{1}$, G.H. Ma ${ }^{2}$, B.H. Du ${ }^{1}$, B. Shen ${ }^{1}$, Y.Q. Ding ${ }^{1}$ and K. $\mathrm{Xu}^{3}$

${ }^{1}$ College of Life Science, Taian, Shandong Province, China

${ }^{2}$ Anqiu City Agricultural Bureau, Anqiu, Shandong Province, China

${ }^{3}$ College of Horticulture Science and Engineering, Taian, Shandong Province, China

Corresponding authors: Y.Q. Ding / K. Xu

E-mail: dingyq6885@163.com / xukun@sdau.edu.cn

Genet. Mol. Res. 13 (3): 4918-4931 (2014)

Received April 10, 2013

Accepted November 21, 2013

Published July 4, 2014

DOI http://dx.doi.org/10.4238/2014.July.4.6

\begin{abstract}
Here, 248 endophytic bacterial strains were isolated to assess the distribution and population diversity of endophytic bacteria in ginger plants. A total of $10.4 \times 10^{4}$ to $20.2 \times 10^{4} \mathrm{CFU} / \mathrm{g}$ fresh weight endophytic bacteria of different growth stages were isolated. Maximum bacterium numbers were obtained at the seedling stage. A total of 107 functional strains were screened, including 17 antibacterial strains and 90 indole acetic acid-producing strains. Based on 16S rDNA sequence restriction fragment length polymorphism and 16S rDNA sequences, these 107 strains were mapped and grouped into 16 genera. Bacillus and Pseudomonas were the dominant genera; however, the bacteria belonged to a tremendous range of genera, with the highest species richness being observed at the seedling stage. Sixteen strains exhibited antimicrobial activity against Pythium myriotylum Drechsler, while 7 strains exhibited antimicrobial activity against Phyllosticta zingiberi Hori. Bacillus was the dominant antibacterial strain. Pseudomonas fluorescens, B. megaterium, and Enterobacter ludwigii produced remarkably high levels of IAA. Only a few endophytic bacterial
\end{abstract}


strains were inhibited in fresh ginger juice. Most of these strains were present during seedling stage, including Roseateles depolymerans, Chryseobacterium taiwanense, E. ludwigii, Agrobacterium larrymoorei, P. fluorescens, and Bacillus amyloliquefaciens. This study indicates that the community of endophytic bacteria in ginger changes with the synthesis of antibacterial substances.

Key words: Endophytic bacteria; IAA; Ginger; Antifungal activity

\section{INTRODUCTION}

Ginger is the rhizomes of Zingiber officinale Roscoe (Zingiberaceae), and has been widely used as a spice and condiment in a range of forms. In addition to its food additive function, ginger has a long history of medicinal use in the treatment of a variety of human diseases, including common colds, fever, rheumatic disorders, gastrointestinal complications, motion sickness, diabetes, and cancer, among others (Kundu et al., 2009). Because of the high yields and economic benefits of ginger, Shandong Province has been developed into the largest ginger planting base in China. Ginger contains many nutrients, including saccharides, fats, proteins, carotenes, vitamin C, and a large number of microelements. Ginger also secretes various substances, such as gingerol, shogaol, zingerone, and ginger essential oil (Singh et al., 2003). Gingerol and ginger essential oil have antibacterial effects against Bacillus subtilis, Escherichia coli, Saccharomyces, Staphylococcus aureus, Aspergillus niger, and Rhizopus (Zhao, 2008).

Endophytic bacteria play an important role in plant growth. Endophytes colonize plant tissues, and are able to interact among themselves and with invaders (e.g., pathogens); thus, influencing plant development. Evolutionarily, endophytes also appear to form an intermediate group between saprophytic bacteria and plant pathogens. Endophytic bacteria have been isolated from a variety of plants, because they ubiquitously inhabit most plant species, including sugar beet, several potato varieties, and poplar trees (Sessitsch et al., 2002; Dent et al., 2004; Taghavi et al., 2009). Many studies have shown that endophytes are widely present in plant tissues, such as the roots, stems, leaves, and flowers (Kobayashi and Palumbo, 2000). For instance, several genera have been isolated from legume tissues, including Aerobacter, Aeromonas, Agrobacterium, Bacillus, Chryseomonas, Curtobacterium, Enterobacter, Erwinia, Flavimonas, Pseudomonas, and Sphingomonas (Sturz et al., 1997; Elvira-Recuenco and van Vuurde, 2000; Oehrle et al., 2000).

Many researchers have studied the breeding and cultivation characteristics of ginger. However, investigations about the endophytic bacteria that this plant harbors remain limited. Some endophytic bacteria have been screened in ginger, and were found to promote plant growth (Xie et al., 2009). Rajan et al. (2000) studied the effects of 4 isolates of endophytic bacteria on the growth of a ginger cultivar (cv.). They also assessed the suppressive activity of endophytic bacteria against Phythium sp, Fusarium oxysporum, and Pratylenchus coffeae in a pot experiment. Chu et al. (2011) analyzed the diversity of endophytes isolated from the ginger tuber.

Endophytes influence plant growth via several processes, including the production of plant hormones. One such hormone is indole-3-acetic acid (IAA), which is an essential phytohormone that is involved in different plant developmental processes (Liu et al., 2010). The 
production of IAA is widely distributed among plant-associated bacteria. While the combined actions of several rhizobacteria seem to result in the promotion of plant growth, bacterial phytohormone production, particularly IAA, is still considered the primary mechanism that enhances the growth and yield of plants (Arkhipova et al., 2005). Another important function of plant growth-promoting bacteria is their antagonistic action against pathogenic microorganisms. Endophytic bacteria interact collaboratively with plant hosts, and are easy to cultivate in vivo. Thus, the investigation of endophytic bacterial functions and subsequent development of their use in plants is of importance to microbiologists and plant protection experts.

Because ginger secretes gingerol and other antibacterial substances during growth, changes in the endogenous bacterial population of ginger are expected to differ compared to bacterial populations in other crops. So the bacterial strains isolating from ginger were used in ginger, which are not only biocontrol or promoting-growth function, but also should be adaptation to different ginger growth stages (Policegoudra et al., 2007). This paper studies the ginger endophytic bacterial population change rule at ginger different growth stages, and provides strain resources and a theoretical basis for bacterial agents that promote the growth and bio-control of ginger. The current study is the first report about the evolutionary changes of endophytic bacteria throughout the different growth stages of ginger.

\section{MATERIAL AND METHODS}

\section{Sampling}

Healthy ginger plants were sampled at 3 different growth stages; specifically, the seedling stage, the stem and leaf vigorous growth stage, and the rhizome enlargement stage. Samples were collected from the same field plot in Qiujiadian, Taian, Shandong Province, China.

\section{Surface sterilization of plants and isolation of endophytic bacteria}

Total endophytic bacteria were isolated from the roots, stems, tubers, and leaves of ginger. Whole plants were first washed with tap water to remove attached clay. Ten grams of tissue from each of the specified plant parts was cut with a sterile surgical knife for surface sterilization. The collected plant materials were immersed in $75 \%$ ethanol for $2.5 \mathrm{~min}$, rinsed with $3 \%$ sodium hypochlorite $(\mathrm{NaClO})$ for $2 \mathrm{~min}$, dipped in $75 \%$ ethanol for $30 \mathrm{~s}$, and finally washed 5 times with sterile distilled water. To determine whether the sterilization process was successful, $100 \mu \mathrm{L}$ water from the third rinsing was plated on $\mathrm{R}_{2} \mathrm{~A}$ medium $(0.05 \%$ proteose peptone, $0.05 \% \mathrm{starch}$, $0.05 \%$ glucose, $0.05 \%$ yeast extract, $0.05 \%$ casein hydrolysate, $0.03 \%$ dipotassium phosphate, $0.03 \%$ sodium pyruvate, $0.0024 \%$ magnesium sulfate anhydrous, $2 \% \mathrm{w} / \mathrm{v}$ agar, $\mathrm{pH} 7.2 \pm 0.2$ ), which was also the medium used for the isolation and purification of endophytic bacteria (Kawai et al., 2002). The plates were incubated at $28^{\circ} \mathrm{C}$ for 1-3 days to determine surface sterilization efficacy. If bacterial colonies were not observed on the plates, the sterilization process was considered successful. All surface-sterilized samples were placed in a sterilized mortar, and thoroughly ground after the addition of $10 \mathrm{~mL}$ sterile distilled water. The resulting suspension was diluted 10 -fold with sterile distilled water, and about $100 \mu \mathrm{L}$ of each dilution was spread onto $\mathrm{R}_{2} \mathrm{~A}$ medium. Bacterial isolates were obtained after incubation at $28^{\circ} \mathrm{C}$ for $2-3$ days. Glycerol was then added, and the purified isolates were kept frozen at $-80^{\circ} \mathrm{C}$ until use. 


\section{Total DNA extraction and 16S rDNA PCR amplification}

Total bacterial DNA isolation was completed according to the procedure of Murray and Thompson (1980). 16S rDNA PCR amplification was carried out with the universal primers 27f (5'-AGAGTTTGATCCTGGCTCAG-3') and 1492r (5'-TACGGCTACCTTGTTA CGACTTCACCCC-3') by using a (Biometra TGRADIENT) thermocycler. The PCR conditions were as follows: initial denaturation at $95^{\circ} \mathrm{C}$ for $4 \mathrm{~min}$, followed by 32 cycles of denaturation at $94^{\circ} \mathrm{C}$ for $45 \mathrm{~s}$, annealing at $56^{\circ} \mathrm{C}$ for $1 \mathrm{~min}$, extension at $72^{\circ} \mathrm{C}$ for $1.5 \mathrm{~min}$, and a final extension at $72^{\circ} \mathrm{C}$ for $10 \mathrm{~min}$. Products of about $1500 \mathrm{bp}$ long were monitored by electrophoresis on $1 \%(\mathrm{w} / \mathrm{v})$ agarose gel at $110 \mathrm{~V}$ for $30 \mathrm{~min}$ in $1 \mathrm{X}$ Tris-boric acid-EDTA (TBE) buffer. PCR products were viewed by ethidium bromide (EB) staining and UV transillumination.

\section{ARDRA analysis of 16S rRNA gene sequences and evolutionary analysis}

A 3S Spin PCR Product Purification Kit (Shenergy Biocolor Bioscience and Technology Company, China) was used for PCR product purification following manufacturer protocols. Purified PCR products were digested using 3 restriction enzymes, AluI, HaeI, and MspI (TaKaRa Biotechnology Co., Ltd., Dalian, China), in separate reactions. The selection of these restriction enzymes was based on the study of Laguerre et al. (1994). Digestion reactions were performed for $4 \mathrm{~h}$ at $37^{\circ} \mathrm{C}$ in a reaction volume of $10 \mu \mathrm{L}$ containing $5 \mu \mathrm{L}$ purified PCR products, $1 \mu \mathrm{L}$ commercially supplied $10 \mathrm{X}$ incubation buffer, $3.5 \mu \mathrm{L}$ water, and $0.5 \mu \mathrm{L}(10 \mathrm{U} /$ $\mu \mathrm{L})$ restriction enzyme. Reaction products $(10 \mu \mathrm{L})$ were run on $2.5 \%(\mathrm{w} / \mathrm{v})$ agarose gel in $1 \mathrm{X}$ TBE buffer for $2.5 \mathrm{~h}$ at $120 \mathrm{~V}$ under refrigeration. Agarose gels were stained, visualized, and digitalized as previously described.

Visible bands greater than 100 bp were used for dendrogram construction. From the banding patterns generated by each of the restriction enzymes, a binary data matrix was constructed based on the presence or absence of each band (coded as 1 or 0 , respectively). To obtain a single pattern for each isolate, the banding patterns obtained from each of the enzymes were combined. The patterns were then used to construct a dendrogram using the unweighted pair group method with arithmetic averages (UPGMA) by a clustering algorithm that makes use of the Sorensen's coefficient along with fine optimization options, which was incorporated into the MultiVariate Statistical Package (MVSP) version 3.13h (GeoMem, Blairgowrice, UK).

\section{S rRNA gene sequencing and sequence analysis}

Purified PCR products obtained from the isolates of each ARDRA group were sequenced. The NCBI (National Center for Biotechnology Information database) nucleotidenucleotide BLAST (BLASTn) tool (http://blast.ncbi.nlm.nih.gov/Blast.cgi) was used to locate closely identical sequences for the 16S rRNA gene sequences that were determined. Highsimilarity sequences, as well as $16 \mathrm{~S}$ rRNA gene sequences of the type strains, were retrieved from the Ribosomal Database Project. The sequences were aligned using the CLUSTAL X software version 1.8. Evolutionary distances were calculated using the package TREECON software version $1.3 \mathrm{~b}$. Construction of a neighbor-joining tree and bootstrap analysis (1000 replicates) was also performed using TREECON (Tamura et al., 2007). 


\section{In vitro antagonistic spectrum bioassay}

An antagonistic spectrum bioassay of the endophytic bacteria was performed with Pythium myriotylum Drechsler and Phyllosticta zingiberi Hori. Bacterial isolates were inoculated on the margin of the fungal colony with sterile toothpicks, and incubated at $28^{\circ} \mathrm{C}$ for $2-4$ days. Growth inhibition was calculated using the formula R1/R2, where R1 is the maximum radius of the fungal colony away from the bacterial colony and $\mathrm{R} 2$ is the average radius of the bacterial colony.

\section{Screening of IAA-producing bacterial isolates and quantitative analysis}

IAA-producing bacteria were screened by growing the bacterial isolates on $\mathrm{R}_{2} \mathrm{~A}$ medium modified with L-tryptophan $(200 \mathrm{mg} / \mathrm{L})$ at $28^{\circ} \mathrm{C}$ and $180 \mathrm{rpm}$ for 3 days. Fifty microliters each of the bacterial liquid cultures and Salkowski reagent were mixed and viewed on a white board background. After being kept in the dark for $30 \mathrm{~min}$, IAA-producing bacteria were identified by a change in color from pink to red. The concentration of IAA-positive strain cultures was measured at $600 \mathrm{~nm}$ before centrifugation at 10,000 rpm for $10 \mathrm{~min}$. The procedures of Glickmann and Dessaux (1995) were used to evaluate IAA production in the supernatant, and a standard curve was generated using pure IAA.

\section{Detection of the bacteriostatic effect of fresh ginger juice}

Peeled ginger was immersed in $75 \%$ ethanol for $2.5 \mathrm{~min}$, and then rinsed with $3 \%$ $\mathrm{NaClO}$ for $2 \mathrm{~min}$. The samples were then dipped in $75 \%$ ethanol for $30 \mathrm{~s}$, and washed 5 times with sterile distilled water. The fresh ginger juice, obtained using a disinfected juicer, was used to produce 4 concentrations of ginger solution: 100, 50, 25, and 10\%. Endophytic bacterial strains were suspended in physiological saline at concentrations ranging from $10^{5}$ to $10^{6}$. Sterilized filter papers $(6 \mathrm{~mm})$ were immersed in various concentrations of ginger juice for $12 \mathrm{~h}$, and then dried at $28^{\circ} \mathrm{C}$. The endophytic bacterial suspensions were then inoculated on the $R_{2} A$ culture plates at a volume of $500 \mathrm{~mL}$. The filter papers that had been immersed in ginger juice were placed on the culture plates containing endophytic bacteria. Each plate contained two of the filter papers for each concentration level, and experiments were performed in triplicate. The plates were incubated at $28^{\circ} \mathrm{C}$ for 1 day. The diameter of the observed inhibition zone was measured for each setup, and the data were recorded. Filter papers immersed in $0.5 \% \mathrm{CuSO}_{4}$ were used as controls.

\section{RESULTS}

\section{Endophytic isolates of ginger plants}

Based on phenotypic characterization, a total of 248 isolates were obtained (Table 1). Bacterial densities from different ginger growth stages were counted, with densities ranging from $10.4 \times 10^{4}$ to $20.2 \times 10^{4} \mathrm{CFU} / \mathrm{g}$ fresh weight. These data produced significant period differences. The highest density was observed at the seedling stage, whereas the lowest density was observed at the rhizome enlargement stage. We also found that ginger leaves have the largest number of endogenous bacteria with the lowest bacterial numbers being observed in stems and tubers (Table 1). 
Table 1. Number of endophytic bacteria determined at different growth stages.

\begin{tabular}{lcccccc}
\hline Growth stage & No. of isolates & Leaf density & Stem density & Tuber density & Root density & Population density \\
\hline Seedling stage & 95 & $12.1 \times 10^{4}$ & $1.0 \times 10^{4}$ & $0.8 \times 10^{4}$ & $6.3 \times 10^{4}$ & $20.2 \times 10^{4}$ \\
Stem and leaf vigorous growth stage & 88 & $8.3 \times 10^{4}$ & $0.6 \times 10^{4}$ & $0.6 \times 10^{4}$ & $4.7 \times 10^{4}$ & $14.2 \times 10^{4}$ \\
Rhizome enlargement stage & 55 & $5.4 \times 10^{4}$ & $0.5 \times 10^{4}$ & $0.4 \times 10^{4}$ & $4.1 \times 10^{4}$ & $10.4 \times 10^{4}$ \\
\hline
\end{tabular}

Data are reported as CFU/g fresh weight.

Bacteria isolated from the seedling stage included Bacillus, Chryseobacterium, Pseudomonas, Flavobacterium, Agrobacterium, Serratia, Roseateles, Sphingomonas, Leclercia, and Enterobacter. Bacteria isolated from the stem and leaf vigorous growth stage included Bacillus, Paenibacillus, Pseudomonas, Agrobacterium, Aeromonas, Acetobacter, Roseateles, Sphingomonas, Enterobacter, and Pantoea. Bacteria isolated in the rhizome enlargement stage included Bacillus, Pseudomonas, Herbaspirillum, Agrobacterium, Ensifer, and Stenotrophomonas.

\section{Antimicrobial activity}

All of the isolates were subjected to antagonism experiments. Among the endophytic isolates, 17 were found to be active against at least 1 of the 2 pathogenic fungi used in this experiment (Table 2). Sixteen strains with antagonistic effects against $P$. myriotylum Drechsler and 6 strains with pathogenic effects against $P$. zingiberi Hori were observed. Furthermore, 5 strains were observed to have antagonistic effects against both types of pathogenic bacteria.

\begin{tabular}{lcc}
\multicolumn{2}{c}{ Table 2. Antifungal activities of the endophytic isolates. } \\
\hline Isolate & Pythium myriotylum Drechsler & Phyllosticta zingiberi Hori \\
\hline EG-14 & +++ & - \\
EG-42 & - & +++ \\
EG-47 & +++ & + \\
RS-163 & +++ & +++ \\
RS-164 & +++ & + \\
RS-169 & +++ & - \\
RS-171 & ++ & ++ \\
RS-106 & ++ & - \\
RS-174 & ++ & - \\
RS-178 & +++ & - \\
RS-179 & ++ & - \\
RS-181 & ++ & - \\
RS-183 & ++ & - \\
RS-184 & +++ & + \\
RS-185 & +++ & + \\
RS-188 & ++ & + \\
RS-195 & ++ & + \\
\hline
\end{tabular}

Inhibition: $(+)=0<\mathrm{R} 1 / \mathrm{R} 2<1 ;(++)=1 \leq \mathrm{R} 1 / \mathrm{R} 2<2 ;(+++)=2 \leq \mathrm{R} 1 / \mathrm{R} 2<2.5 ;(-)=\mathrm{R} 1 / \mathrm{R} 2<0 . \mathrm{R} 1$ is the maximum radius of the fungal colony away from the bacterial colony. $\mathrm{R} 2$ is the average radius of the bacterial colony.

\section{ARDRA analysis, sequencing, and phylogeny}

From the digestion patterns of the restriction enzymes, a dendrogram (Figure 1) was constructed based on the banding patterns obtained by the NTSYS 2.1 program. 


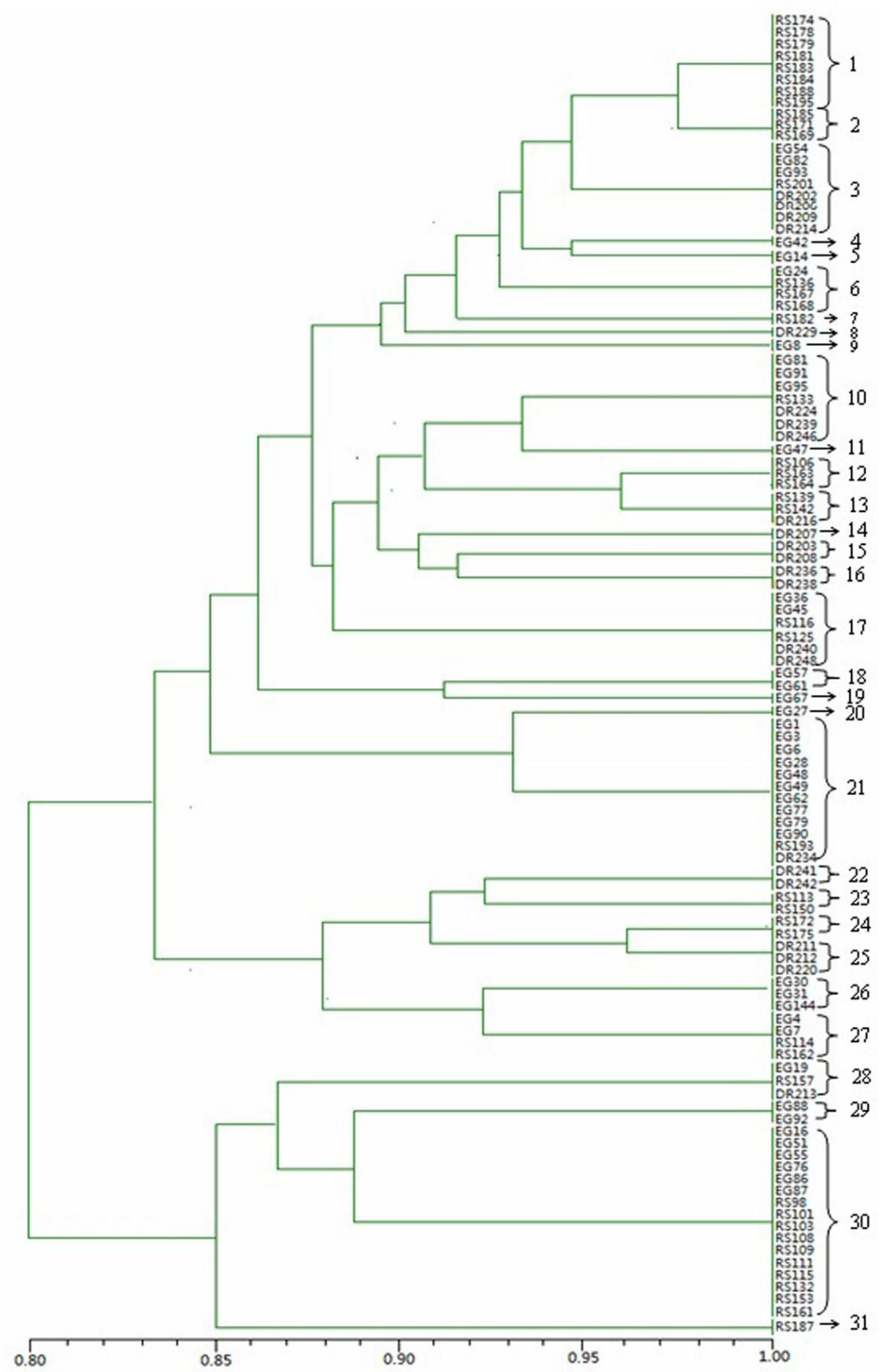

Figure 1. Dendrogram showing the relationships of 107 endophytic bacteria based on 16S-RFLP fingerprints obtained using cluster analysis. 
The obtained isolates, 90 of which were IAA-producing and 17 of which featured activity against other strains, were divided into 31 clusters (or genotypic groups) with $100 \%$ similarity and 1 group with $80 \%$ similarity. Six large groups were formed (group 1, group 3 , group 10, group 17, group 21, and group 30), with a further 15 small groups and 10 groups of just one isolate. The other groups contained various numbers of isolates. Thirty-one representative isolates from each group were sequenced and subsequently analyzed using the NCBI BLASTn program to retrieve annotated sequences (Table 3).

\begin{tabular}{|c|c|c|c|c|c|}
\hline 16S-RFLP groups & No. & Isolate & Accession No. & Closest NCBI strain and accession No. & Similarity $(\%)$ \\
\hline 1 & 8 & RS178 & KC122683 & Bacillus amyloliquefaciens AB006920.1 & 99 \\
\hline 2 & 3 & RS169 & KC122684 & Bacillus methylotrophicus EU194897.1 & 99 \\
\hline 3 & 8 & EG54 & KC122685 & Bacillus thuringiensis D16281.1 & 99 \\
\hline 4 & 1 & EG42 & KC122686 & Bacillus altitudinis AJ831842 & 99 \\
\hline 5 & 1 & EG14 & KC122687 & Bacillus cereus AE016877.1 & 99 \\
\hline 6 & 4 & EG24 & KC122688 & Bacillus megaterium D16273.1 & 99 \\
\hline 7 & 1 & RS182 & KC122689 & Paenibacillus hunanensis EU741036.2 & 99 \\
\hline 8 & 1 & DR229 & KC122690 & Herbaspirillum aquaticum FJ267649.1 & 99 \\
\hline 9 & 1 & EG8 & KC122691 & Chryseobacterium taiwanense DQ318789.1 & 99 \\
\hline 10 & 7 & DR239 & KC122692 & Pseudomonas fluorescens D84013.1 & 99 \\
\hline 11 & 1 & EG47 & KC122693 & Pseudomonas aeruginosa X06684.1 & 99 \\
\hline 12 & 1 & RS163 & KC122694 & Pseudomonas monteilii AF064458.1 & 99 \\
\hline 13 & 3 & RS139 & KC122695 & Pseudomonas taiwanensis EU103629.2 & 99 \\
\hline 14 & 1 & DR207 & KC122696 & Pseudomonas mendocina AM088473.1 & 99 \\
\hline 15 & 2 & DR203 & KC122697 & Pseudomonas putida D84020.1 & 99 \\
\hline 16 & 2 & DR236 & KC122698 & Pseudomonas pseudoalcaligenes Z76666.1 & 99 \\
\hline 17 & 6 & RS116 & KC122699 & Pseudomonas huttiensis AB021366.1 & 99 \\
\hline 18 & 2 & EG57 & $\mathrm{KC} 122700$ & Flavobacterium johnsoniae AM230489.1 & 99 \\
\hline 19 & 1 & EG67 & $\mathrm{KC} 122701$ & Flavobacterium reichenbachii AM177616.1 & 99 \\
\hline 20 & 1 & EG27 & KC122702 & Agrobacterium larrymoorei Z30542.1 & 99 \\
\hline 21 & 12 & EG77 & KC122703 & Agrobacterium tumefaciens D14500.1 & 99 \\
\hline 22 & 2 & DR242 & KC122704 & Ensifer adhaerens AM181733.1 & 99 \\
\hline 23 & 2 & RS113 & KC122705 & Aeromonas trotsa $\mathrm{X} 60415.2$ & 99 \\
\hline 24 & 2 & RS172 & KC122706 & Acetobacter pasteurianus $\mathrm{X} 71863.1$ & 99 \\
\hline 25 & 3 & DR220 & KC122707 & Stenotrophomonas maltophilia AB294553.1 & 99 \\
\hline 26 & 3 & EG30 & KC122708 & Serratia nematodiphila EU036987.1 & 99 \\
\hline 27 & 4 & EG4 & KC122709 & Roseateles depolymerans AB003623.1 & 99 \\
\hline 28 & 3 & EG19 & KC122710 & Sphingomonas yabuuchiae AB071955.2 & 99 \\
\hline 29 & 2 & EG88 & KC122711 & Leclercia adecarboxylata JN175338.1 & 99 \\
\hline 30 & 16 & EG16 & $\mathrm{KC} 122712$ & Enterobacter ludwigii AJ853891.1 & 99 \\
\hline 31 & 1 & RS187 & $\mathrm{KC} 122713$ & Pantoea ananatis U80196.1 & 99 \\
\hline Total & 107 & & & & \\
\hline
\end{tabular}

The phylogenetic tree (Figure 2) constructed from the 16S rDNA sequences showed that 31 isolates were clustered into 17 different genera. Pseudomonas, Bacillus, Agrobacterium, and Enterobacter, consisting of 23, 25, 13, and 16 isolates, respectively, were the dominant genera identified.

\section{IAA-producing species}

A total of 90 IAA-producing endophytic bacteria were obtained from the 3 growth stages. IAA production ranged between 7.45 and $162.90 \mathrm{mg} / \mathrm{L}^{-1}\left(\mathrm{OD}_{600}\right)^{-1}$ (Table 4). Quantitative analysis revealed that samples with high levels of IAA production included Pseudomonas, Pantoea agglomerans, Aeromonas, Serratia, Enterobacter asburiae, and Rhizobium. 

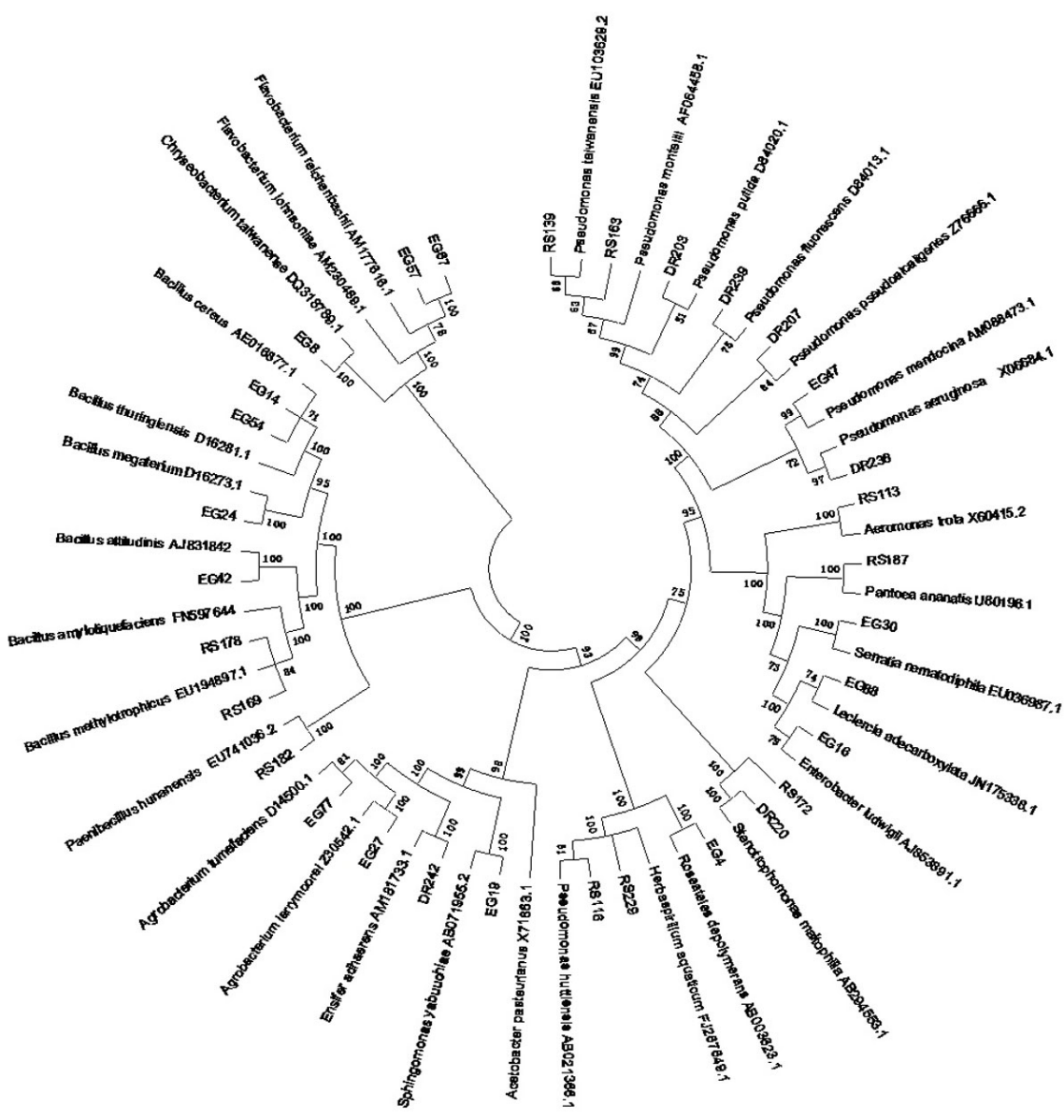

Figure 2. Neighbor-joining phylogenetic tree based on 16S rRNA gene sequences of endophytic bacteria and the closest type strain for each isolate.

\section{Antibacterial effects of fresh ginger juice}

The experimental results showed that only a few endophytic bacterial strains were inhibited by fresh ginger juice. Most of the strains were isolated from the seedling stage, including Roseateles depolymerans, Chryseobacterium taiwanense, Enterobacter ludwigii, Agrobacterium larrymoorei, Pseudomonas fluorescens, and B. amyloliquefaciens. These results indicate that most endophytic bacteria isolated from ginger may be used to internally colonize ginger. At the seedling stage of ginger, when the tuber is just beginning to grow, numerous endophytic bacteria may colonize the root and be transported into the plant because of relatively low gingerol levels. Gingerol content increases with the growth of ginger, resulting in the inhibition of certain endophytic bacteria. Gingerol levels are high during the stem and leaf vigorous growth stage and rhizome enlargement stage. Thus, endophytic bacteria obtained at these stages are not inhibited by fresh ginger juice. 


\begin{tabular}{|c|c|c|c|c|c|}
\hline & Isolates & $\begin{array}{l}\text { IAA production } \\
{\left[\mathrm{mg} \cdot \mathrm{L}^{-1} \cdot\left(\mathrm{OD}_{600}\right)^{-1}\right]}\end{array}$ & & Isolates & $\begin{array}{l}\text { IAA production } \\
{\left[\mathrm{mg} \cdot \mathrm{L}^{-1} \cdot\left(\mathrm{OD}_{600}\right)^{-1}\right]}\end{array}$ \\
\hline \multirow[t]{7}{*}{ P. fluorescens } & EG81 & $88.96 \pm 0.2$ & A. tumefaciens & EG1 & $16.14 \pm 0.3$ \\
\hline & DR239 & $81.62 \pm 0.4$ & & EG3 & $9.10 \pm 0.2$ \\
\hline & EG91 & $92.33 \pm 0.7$ & & EG6 & $11.00 \pm 0.3$ \\
\hline & RS95 & $80.83 \pm 0.2$ & & EG28 & $12.23 \pm 0.3$ \\
\hline & RS133 & $86.09 \pm 0.3$ & & EG48 & $12.46 \pm 0.4$ \\
\hline & DR224 & $99.07 \pm 0.2$ & & EG49 & $9.22 \pm 0.2$ \\
\hline & DR246 & $81.63 \pm 0.3$ & & EG62 & $15.86 \pm 0.3$ \\
\hline \multirow[t]{3}{*}{ P. taiwanensis } & RS139 & $28.15 \pm 0.3$ & & EG77 & $13.28 \pm 0.3$ \\
\hline & RS142 & $26.02 \pm 0.4$ & & EG79 & $18.33 \pm 0.4$ \\
\hline & DR216 & $27.58 \pm 0.5$ & & EG90 & $11.45 \pm 0.6$ \\
\hline \multirow[t]{2}{*}{ P. putida } & DR203 & $26.71 \pm 0.4$ & & RS193 & $5.64 \pm 0.4$ \\
\hline & DR208 & $27.11 \pm 0.3$ & & DR234 & $9.27 \pm 0.5$ \\
\hline P. mendocina & DR207 & $60.87 \pm 0.2$ & E. adhaerens & DR241 & $45.19 \pm 0.4$ \\
\hline \multirow[t]{2}{*}{ P. pseudoalcaligenes } & DR236 & $45.99 \pm 0.3$ & & DR242 & $40.20 \pm 0.5$ \\
\hline & DR238 & $46.81 \pm 0.3$ & S. yabuuchiae & EG19 & $46.62 \pm 0.3$ \\
\hline \multirow[t]{16}{*}{ E. ludwigii } & EG16 & $96.87 \pm 0.4$ & & RS157 & $48.91 \pm 0.2$ \\
\hline & EG51 & $114.52 \pm 0.6$ & & DR213 & $47.51 \pm 0.3$ \\
\hline & EG55 & $90.12 \pm 0.2$ & P. huttiensis & EG36 & $45.05 \pm 0.2$ \\
\hline & EG76 & $99.21 \pm 0.5$ & & EG45 & $30.94 \pm 0.2$ \\
\hline & EG86 & $97.99 \pm 0.3$ & & RS116 & $37.56 \pm 0.1$ \\
\hline & EG87 & $94.68 \pm 0.5$ & & RS125 & $37.64 \pm 0.2$ \\
\hline & RS98 & $93.18 \pm 0.4$ & & DR240 & $52.15 \pm 0.2$ \\
\hline & RS101 & $104.49 \pm 0.5$ & & DR248 & $41.50 \pm 0.1$ \\
\hline & RS103 & $121.93 \pm 0.3$ & H. aquaticum & DR229 & $85.55 \pm 0.2$ \\
\hline & RS108 & $105.16 \pm 0.2$ & $R$. depolymerans & EG4 & $12.45 \pm 0.2$ \\
\hline & RS109 & $96.80 \pm 0.3$ & & EG7 & $15.18 \pm 0.3$ \\
\hline & RS111 & $162.90 \pm 0.3$ & & RS114 & $10.97 \pm 0.2$ \\
\hline & RS115 & $111.19 \pm 0.2$ & & RS162 & $17.75 \pm 0.3$ \\
\hline & RS132 & $103.92 \pm 0.3$ & F. reichenbachii & EG67 & $27.25 \pm 0.2$ \\
\hline & RS153 & $123.40 \pm 0.2$ & F. johnsoniae & EG57 & $72.50 \pm 0.2$ \\
\hline & RS161 & $148.48 \pm 0.3$ & & EG61 & $63.23 \pm 0.2$ \\
\hline \multirow[t]{2}{*}{ L. adecarboxylata } & EG88 & $77.84 \pm 0.2$ & C. taiwanense & EG8 & $76.41 \pm 0.3$ \\
\hline & EG92 & $72.78 \pm 0.3$ & B. megaterium & EG24 & $126.84 \pm 0.2$ \\
\hline \multirow[t]{3}{*}{ S. nematodiphila } & EG30 & $77.10 \pm 0.2$ & & RS136 & $120.80 \pm 0.2$ \\
\hline & EG31 & $73.64 \pm 0.2$ & & RS167 & $122.02 \pm 0.2$ \\
\hline & RS144 & $75.82 \pm 0.2$ & & RS168 & $123.46 \pm 0.4$ \\
\hline Pantoea ananatis & RS187 & $78.85 \pm 0.2$ & B. thuringiensis & EG54 & $8.88 \pm 0.2$ \\
\hline \multirow[t]{2}{*}{ A. pasteurianus } & RS172 & $18.50 \pm 0.2$ & & EG82 & $3.95 \pm 0.3$ \\
\hline & RS175 & $20.11 \pm 0.1$ & & EG93 & $2.58 \pm 0.2$ \\
\hline \multirow[t]{3}{*}{ S. maltophilia } & DR220 & $15.45 \pm 0.2$ & & RS201 & $4.97 \pm 0.3$ \\
\hline & DR211 & $10.31 \pm 0.2$ & & DR202 & $8.76 \pm 0.2$ \\
\hline & DR212 & $10.21 \pm 0.2$ & & DR206 & $2.26 \pm 0.1$ \\
\hline \multirow[t]{2}{*}{ A. trotsa } & RS113 & $86.04 \pm 0.2$ & & DR209 & $3.62 \pm 0.2$ \\
\hline & RS150 & $91.69 \pm 0.3$ & & DR214 & $3.97 \pm 0.4$ \\
\hline A. larrymoorei & EG27 & $80.78 \pm 0.2$ & P. hunanensis & DR182 & $17.32 \pm 0.2$ \\
\hline
\end{tabular}

Data are reported as means \pm SE from triplicate samples.

\section{DISCUSSION}

Endophytic bacteria are important constituents of the plant micro-ecological system, providing resources that promote crop growth and plant disease prevention (Forchetti et al., 2010). In this study, a large number of endophytic bacterium species from a diverse range of genera were found in ginger plants. Based on the clustering results of ARDRA and 16S rRNA gene sequencing, 107 isolates were separated into 16 different genera and at least 31 different species, representing a wide variety of endophytic bacteria. The results indicate that the numbers and types of endophytic bacteria present decrease as the host ginger grows, which supported the results obtained from the colony count and 16S rDNA sequencing data. 
The most dominant genera were Bacillus and Pseudomonas, both of which were found in all 3 growth stages. Chryseobacterium, Flavobacterium, Serratia, and Leclercia were only found in the seedling stage. Paenibacillus, Aeromonas, Acetobacter, and Pantoea were only found in the stem and leaf vigorous growth stage. Herbaspirillum, Ensifer, and Stenotrophomonas were only found in the rhizome enlargement stage. The seedling stage yielded the highest number of endophyte species, whereas the rhizome enlargement stage yielded the least. Colony counting showed that the maximum density of endophytic bacteria appears during the seedling stage. In contrast, the minimum density of bacteria appeared in the rhizome enlargement stage. Chu et al. (2011) isolated 23 endophytes from a ginger tuber cultivar, 8 of which were sequenced and analyzed. In their study, the strains fell into the following genera: Pseudomonas spp, Bacillus spp, Brachybacterium spp, Stenotrophomonas spp, and Rahnella spp. In comparison, 23 different genera were identified in the current study. Distinct changes in the quantity of the endophytic population, with a peak occurring at the stem and leaf vigorous growth stage, were observed. This observation proves that colony counts are not consistent across different stages of growth. We also found that ginger leaves have the largest number of endogenous bacteria, followed by the roots, stems, and tubers. Fluctuations in the number of retrieved endophytic microorganisms seem to be influenced by both the host plant and the surrounding environment.

Ninety IAA-producing isolates and 17 antagonistic strains were isolated and screened from the ginger plants during the 3 growth stages. A significant change in bacterial diversity was observed among the growth stages. Six Bacillus spp (Table 4) were isolated in this study, with their sequences aligning with those of $B$. amyloliquefaciens, $B$. methylotrophicus, $B$. thuringiensis, $B$. altitudinis, $B$. cereus, and $B$. megaterium. The results showed that $B$. cereus, $B$. methylotrophicus, and $B$. amyloliquefaciens exhibit antimicrobial activities against $P$. myriotylum Drechsler. $B$. altitudinis, which also has a broad antibacterial spectrum, exhibited antimicrobial activity against $P$. zingiberi Hori (Xu et al., 2012). B. thuringiensis, which is extensively used in the biological control of insects, exhibited the lowest IAA production in this study (Vilas-Bôas et al., 2007). The most active IAA producer was B. megaterium, which produced $126.84 \mathrm{mg} \cdot \mathrm{L}^{-1} \cdot\left(\mathrm{OD}_{600}\right)^{-1}$ IAA. This result supports a previous report by Ali et al. (2009), in which B. megaterium was observed to promote the growth of red clover plants, either individually or in combination, with Rhizobium leguminosarum.

$P$. aeruginosa and $P$. monteilii exhibited antimicrobial activity against $P$. myriotylum Drechsler and $P$. zingiberi Hori. Of these 2 bacteria, $P$. monteilii exhibited a higher level of activity. Based on published literature, we found that $P$. aeruginosa and $P$. monteilii also have broad antibacterial spectra. $P$. monteilii has antimicrobial activities against $C y$ lindrocarpon destructans of ginseng, black spot of Dioscorea nipponica Makino, and P. myriotylum Drechsler of Schisandra chinensis (Zhai et al., 2012). P. aeruginosa exhibits antimicrobial activities against Ralstonia solanacearum of tobacco (Dong et al., 2011). Other Pseudomonas isolates from the present study, including $P$. fluorescens, P. taiwanensis, P. mendocina, P. putida, P. pseudoalcaligenes, and $P$. huttiensis, also produce IAA at varying levels. $P$. putida and $P$. fluorescens exhibit antagonistic effects on the tobacco mosaic virus (Wu et al., 2008; Guo et al., 2011).

Previous studies have reported that some IAA-producing endophytic bacteria, such as R. depolymerans, Herbaspirillum aquaticum, Sphingomonas yabuuchiae, and Agrobacterium tumefaciens, have associated nitrogen-fixation functions (Kanvinde and Sastry, 1990; An et al., 1999; Hu et al., 2007; Liu et al., 2011). We also screened E. ludwigii in ginger, which produced both IAA but also ACC deaminase, and showed antimicrobial activity against $E$. coli and $B$. 
subtilis (Gong et al., 2011). Endogenetic bacteria with ACC deaminase play important roles in alleviating plants subject to various stressors, such as drought, water logging, salt, heavy metal, and pressure (Zahir et al., 2008). Other studies have also reported that E. ludwigii in vetiver grass has associated nitrogen-fixation functions, while $E$. ludwigii in cotton and tobacco exhibits antimicrobial activity against Fusarium and Verticillium (Li et al., 2009; Zhao et al., 2009).

Other endophytic bacteria in ginger that also produce IAA include $C$. taiwanense, Flavobacterium johnsoniae, F. reichenbachii, A. larrymoorei, Aeromonas trotsa, Acetobacter pasteurianus, Stenotrophomonas maltophilia, Serratia nematodiphila, Leclercia adecarboxylata, and Pantoea ananatis. Members of the genus Chryseobacterium are relatively common, and have been reported to be present in asparagus lettuce, wheat, and ramie, among other plants (McSpadden Gardener and Weller, 2001; Young et al., 2005; Shao et al., 2010). The present study is the first to report Chryseobacterium as an endophytic bacterium of ginger. F. johnsoniae is found ubiquitously in nature including inhabiting plants, soil, and water, and plays a significant role in the natural material circulation process. They can degrade various bio-macromolecules, such as chitin, glucose, and protein, and play an important role in the natural recycling of substances.

The roles that the endophytic bacteria identified in ginger play toward promoting plant growth have yet to be determined; hence, further experiments are required. This paper revealed changes in endophytic bacterium density and distribution at different growth stages of ginger, in addition to analyzing the antistatic ability of these bacterial groups and their ability to produce IAA. This study serves as a reference for strain resources for the recorded biological agents, and provides a theoretical basis for their subsequent use.

\section{ACKNOWLEDGMENTS}

Research supported by the Special Fund for Agro-Scientific Research in the Public Interest of China (Grant \#200903018).

\section{REFERENCES}

Ali B, Sabri AN, Ljung K and Hasnain S (2009). Quantification of indole-3-acetic acid from plant associated Bacillus spp. and their phytostimulatory effect on Vigna radiata (L.). World J. Microbiol. Biotechnol. 25: 519-526.

An QL and Li JD (1999). Endophytic diazotroph. Plant Physiol. Commun. 35: 265-272.

Arkhipova TN, Veselov SU, Melentiev AI, Martynenko EV, et al. (2005). Ability of bacterium Bacillus subtilis to produce cytokinins and to influence the growth and endogenous hormone content of lettuce plants. Plant Soil 272: 201-209.

Chu M, Zhang Z, Wang W, Song S, et al. (2011). The diversity of endophytes in ginger and screening of the antagonism. Xinjiang Agr. Sci. 48: 2061-2066.

Dent KC, Stephen JR and Finch-Savage WE (2004). Molecular profiling of microbial communities associated with seeds of Beta vulgaris subsp. Vulgaris (sugar beet). J. Microbiol. Methods 56: 17-26.

Dong XW, Miao L, Jin CL, Dong KM, et al. (2011). Isolation and identification of a soil bacterial strain efficiently inhibiting Ralstonia solanacearum in tobacco field. Acta Agr. Jiangxi 23: 30-33.

Elvira-Recuenco M and van Vuurde JW (2000). Natural incidence of endophytic bacteria in pea cultivars under field conditions. Can. J. Microbiol. 46: 1036-1041.

Forchetti G, Masciarelli O, Izaguirre MJ, Alemano S, et al. (2010). Endophytic bacteria improve seedling growth of sunflower under water stress, produce salicylic acid, and inhibit growth of pathogenic fungi. Curr. Microbiol. 61: 485-493.

Gong FJ, Borrathybay E, Zhang YF and Nazierbieke W (2011). Isolation and antibacterial activity of ACC deaminasecontaining endophytic bacteria from Eucommia ulmoides Oliver. Microbiol. China 38: 1526-1532.

Glickmann E and Dessaux Y (1995). A critical examination of the specificity of the salkowski reagent for indolic compounds produced by phytopathogenic bacteria. Appl. Environ. Microbiol. 61: 793-796. 
Guo C, Yang JG, Shen LL, Qian YM, et al. (2011). Screening and identification of Pseudomonas putida strain against TMV. J. South China Agric. Univ. 32: 57-60.

$\mathrm{Hu}$ J, He XH, Li DP and Liu Q (2007). Progress in research of Sphingomonas. Chin. J. Appl. Environ. Biol. 13: 431-437. Kanvinde L and Sastry GRK (1990). Agrobacterium tumefaciens is a diazotrophic bacterium. Appl. Environ. Microbiol. 56: 2087-2092.

Kawai M, Matsutera E, Kanda H, Yamaguchi N, et al. (2002). 16S ribosomal DNA-based analysis of bacterial diversity in purified water used in pharmaceutical manufacturing processes by PCR and denaturing gradient gel electrophoresis. Appl. Environ. Microbiol. 68: 699-704.

Kobayashi DY and Palumbo JD (2000). Bacterial Endophytes and their Effects on Plants and Uses in Agriculture. Micro Endophytes, New York, 199-233.

Kundu JK, Na HK and Surh YJ (2009). Ginger-derived phenolic substances with cancer preventive and therapeutic potential. Forum Nutr. 61: 182-192.

Laguerre G, Allard MR, Revoy F and Amarger N (1994). Rapid identification of rhizobia by restriction fragment length polymorphism analysis of PCR-amplified 16S rRNA genes. Appl. Environ. Microbiol. 60: 56-63.

Li CH, Deng YY, Zhao MW and Tang CM (2009). Population dynamics and antagonism toward Fusarium oxysporium F. sp. vasimfectum and Verticillium dahliae Kleb of endophytic bacteria from cotton. Acta Microbiol. Sin. 49: 1196-1202.

Liu L, Sun L, Zhang RY, Yao N, et al. (2010). Diversity of IAA-producing endophytic bacteria isolated from the roots of Cymbidium goeringii. Biodivers. Sci. 18: 182-187.

Liu Y, Zuo S, Zou YY, Wang JH, et al. (2011). Diversity of endophytic bacterial communities in seeds of hybrid maize (Zea mays L., Nongda 108) and their parental lines. China Agr. Sci. 44: 4763-4771.

McSpadden Gardener BB and Weller DM (2001). Changes in populations of rhizosphere bacteria associated with take-all disease of wheat. Appl. Environ. Microbiol. 67: 4414-4425.

Murray MG and Thompson WF (1980). Rapid isolation of high molecular weight plant DNA. Nucleic Acids Res. 8: 43214325.

Oehrle NW, Karr DB, Kremer RJ and Emerich DW (2000). Enhanced attachment of Bradyrhizobium japonicum to soybean through reduced root colonization of internally seedborne microorganisms. Can. J. Microbiol 46: 600-606.

Policegoudra RS, Abiraj K, Channe GD and Aradhya SM (2007). Isolation and characterization of antioxidant and antibacterial compound from mango ginger (Curcuma amada Roxb.) rhizome. J. Chromatogr. B Analyt. Technol. Biomed. Life Sci. 852: 40-48.

Rajan PP, Gupta SR, Sarma YR and Jackson GVH (2000). Endophytic Bacteria: Its Disease Suppressive and Growth Promotive Activities in Ginger (Zingiber officinale Rosc.). Centennial Conference on Spices and Aromatic Plants, Calicut, 254-258.

Sessitsch A, Reiter B, Pfeifer U and Wilhelm E (2002). Cultivation-independent population analysis of bacterial endophytes in three potato varieties based on eubacterial and actinomycetes-specific PCR of 16S rRNA genes. FEMS Microbiol. Ecol. 39: 23-32.

Shao JH, Yao XW and He SJ (2010). Isolating Cd resistant bacteria from ramie rhizosphere and their effects on the growth and Cd absorptional characters of ramie. J. Agr. Environ. Sci. 29: 487-491.

Singh A, Singh B, Singh A and Singh P (2003). Response of ginger (Zingiber officinale) to metholds of planting and levels of phosphorus in a rehabilitated forest developed on sodic land. J. Spices Aromat. Crop 12: 63-66.

Sturz AV, Christie BR, Matheson BG and Nowak J (1997). Biodiversity of endophytic bacteria that colonized red clover nodules, roots, stems and foliage and their influence on host growth. Biol. Fertil. Soils 25: 13-19.

Taghavi S, Garafola C, Monchy S, Newman L, et al. (2009). Genome survey and characterization of endophytic bacteria exhibiting a beneficial effect on growth and development of poplar trees. Appl. Environ. Microbiol. 75: 748-757.

Tamura K, Dudley J, Nei M and Kumar S (2007). MEGA4: Molecular evolutionary genetics analysis (MEGA) software version 4.0. Mol. Biol. Evol. 24: 1596-1599.

Vilas-Bôas GT, Peruca AP and Arantes OM (2007). Biology and taxonomy of Bacillus cereus, Bacillus anthracis, and Bacillus thuringiensis. Can. J. Microbiol. 53: 673-687.

Wu HH, Wang FG, Shen LL, Chen DX, et al. (2008). Primary studies on the control mechanism of TMV with an antiviral protein. Plant Prot. 34: 74-77.

Xie YF, Liang YL, Yang X, Wang L, et al. (2009). Activities of antibacterial protein form Zingiber officinale rose endophyte. Food Res. Dev. 9: 43-45.

Xu YY, Du BH, Yao LT, Jin FL, et al. (2012). Diversity of antagonistic bacteria isolated from rhizosphere of several cash crops. Ying Yong Sheng Tai Xue Bao 23: 511-518.

Young CC, Kampfer P, Shen FT, Lai WA, et al. (2005). Chryseobacterium formosense sp. nov., isolated from the rhizosphere of Lactuca sativa L. (garden lettuce). Int. J. Syst. Evol. Microbiol. 55: 423-426. 
Zahir ZA, Munir A, Asghar HN, Shaharoona B, et al. (2008). Effectiveness of rhizobacteria containing ACC deaminase for growth promotion of peas (Pisum sativum) under drought conditions. J. Microbiol. Biotechnol. 18: 958-963.

Zhai XL, Yang JG, Shen LL, Qian YM, et al. (2012). Selection and identification of a biocontrol bacteria strain with inhibitory activity against TMV and PVY. China Agr. Sci. 45: 2180-2188.

Zhao J (2008). Studies on the Extraction of Gingerol from Ginger and its Functionality. Master's dissertation, Southwest Jiaotong University, Chengdu.

Zhao X, Javed CH, He Y, Zhang Z, et al. (2009). Diversity of associated nitrogen-fixing bacteria isolated from the pioneer plants - Vetiver zizanioides. Wei Sheng Wu Xue Bao 49: 1430-1437. 